\title{
On the Relationship Between Null Subjects and Agreement: A Large-Scale Cross-Linguistic Account
}

\author{
Ernei Ribeiro Pereira \\ Tohoku University
}

It is generally assumed that languages with rich agreement allow null subjects, while languages with poor agreement do not. However, the concept of agreement richness has been remarkably difficult to define. This study, based on a sample of 403 languages, measures agreement richness by counting the number of person, number, and gender combinations encoded by subject agreement on the verb. It is shown that, among languages with subject agreement on the verb, null subject languages (NSLs) with seven or more such distinctions are the most widespread geographically and genealogically. On the other hand, NSLs without subject agreement on the verb are more widespread than NSLs with seven or more combinations only in Eurasia. Possible explanations for these tendencies are suggested.

\section{Introduction}

In many languages, such as Spanish and Italian, null subjects are allowed (e.g., Comí almendras '(I) ate almonds'), while in others, such as English and French, the subject is obligatory (e.g., *Ate almonds). It is often claimed that in Spanish and Italian the subject agreement on the verb provides rich information on the person and number of the subject, hence allowing null subjects. In a similar vein, it is supposed that English and French do not allow null subjects because they lack rich agreement morphology (Müller 2006, Roberts and Holmberg 2010, D’Alessandro 2015).

Although the relationship between rich agreement and the occurrence of null subjects is apparently clear and there are numerous languages that present evidence of such a relationship, many linguists (Jaeggli and Safir 1989, Speas 2006, Camacho 2013) have noted that defining the notion of rich agreement accurately is very difficult. Modesto (2008:375) indicates that most researchers use the term "rich" to mean "bearing enough morphology to provide non-ambiguous information on the person and number (and maybe gender) of the subject." However, this definition does not make it clear how rich the agreement needs to be to allow null subjects.

The work of Gilligan (1987) partially deals with the relationship between null subjects and agreement, based on a sample of 100 languages. Gilligan points to the fact that both Chinese and Papiamentu do not have subject agreement on the verb, but the former is a null subject language (NSL), and the latter is not. Furthermore, he indicates that both Bavarian German and Standard German have precisely the same set of agreement morphemes, but the former allows null subjects, and the latter does not. Based on these facts, Gilligan (1987:170,220) claims that an agreementbased analysis of null subjects is doomed to failure. However, as his intention is to make exceptionless generalizations, he does not verify for tendencies (e.g., if languages without subject agreement on the verb tend to allow null subjects or not).

Jaeggli and Safir (1989) abandon the notion of rich agreement and claim that null subjects are permitted only in languages with morphologically uniform inflectional paradigms. If a paradigm has all its forms divisible into stem and affix or all its forms are bare stems, then it is uniform. If a paradigm has some of its forms morphologically divisible into stem and affix, while other forms are bare stems, then it is not uniform. Spanish is a language in which all forms in paradigms are divisible into stem and affix, as seen by the present tense suffixes of the verb comer 'eat' in (1). Japanese has no person and number agreement at all, although verbs inflect for tense, aspect, mood, 
and negation, and never have a bare stem. Chinese does not have inflectional morphology at all. The third-person singular of the present tense in English is divisible into the stem and the affix $-S$, while the other person and number combinations are unmarked. The present tense of French is divisible into stem and affix only in the first- and second-person plural, while the other combinations are unmarked, as seen by the phonetic forms of the verb parler 'talk' in (2).

(1)

\begin{tabular}{lll}
\multicolumn{2}{l}{ Spanish } \\
& SG & PL \\
1 & com-o & com-emos \\
2 & com-es & com-éis \\
3 & com-e & com-en
\end{tabular}

(2) French

$\begin{array}{lll} & \text { SG } & \text { PL } \\ 1 & {[\text { parl] }} & {[\text { parl-õ] }} \\ 2 & {[\text { parl] }} & {[\text { parl-e] }} \\ 3 & {[\text { parl] }} & {[\text { parl] }}\end{array}$

Morphological uniformity thus predicts that Spanish, Chinese and Japanese will have null subjects, whereas English and French will not. However, German, Icelandic, and Swedish have morphologically uniform paradigms, but do not allow null subjects. Jaeggli and Safir explain this problematic case by proposing that, as these are V2 languages, tense and agreement occupy separate nodes (1989:33). However, the authors do not consider enough languages to test whether such criteria as morphological uniformity and being a V2 language are accidental or essential.

Speas (2006) claims that null subjects occur in the context of either very rich agreement or no agreement at all. Speas proposes that the expression or otherwise of null subjects is determined by whether the grammatical categories of person and number are specified. If they lack such specification, they must be given value. Following this, languages with poor agreement do not allow null subjects because null subjects do not provide value to such agreement. In languages lacking subject agreement on the verb (like Chinese), null subjects may occur because there is no agreement to give value to. Speas accounts for obligatory subjects in Swedish (which has no subject agreement on the verb) by arguing that this language does not entirely lack agreement, as it has some gender and number agreement between nouns, determiners and adjectives. However, as Neeleman and Szendröi (2007:676) indicate, a theoretical link between null subjects and nominal or adjectival agreement is lacking. Moreover, they point out that there are exceptions to Speas' generalization. For example, Afrikaans lacks agreement altogether and still does not allow null subjects, while Malayalam, a Dravidian language spoken in India, is like Swedish in lacking verbal agreement and having some agreement in the noun phrase, but allows null subjects.

Siewierska (2004:268) points out that languages with subject agreement on the verb and obligatory subjects are cross-linguistically very uncommon. While they are well represented in Western Europe (e.g., Dutch, English, Icelandic, German, and French), only sporadic instances are identified by Siewierska outside this area, namely, in four Papuan languages ( $\mathrm{Au}$, Ekari, Koiari, and Vanimo) and three Oceanic ones (Anejom, Fehan, and Labu). Siewierska (2004:269-270) further shows that most of these languages display considerable agreement syncretism. However, Siewierska (2004:272) recognizes that there are languages that display a good deal of syncretism in their person affixes but do allow null subjects. She gives as an example only Chai, a Surmic language of Ethiopia. Cysouw (2003: 41-56) gives some further examples, such as Chitimacha, an extinct language isolate from the USA, and Wambon, a Nuclear Trans New Guinea language spoken in Indonesia. Siewierska (2004:272) also recognizes that there are languages with nonsyncretic subject agreement that nevertheless require or strongly favor overt subjects. She gives as examples $\mathrm{Au}$ and Fehan. However, it remains unclear, from Siewierska's and Cysouw's investigations, if languages with ambiguous agreement tend to allow null subjects. 
In his chapter "Expression of Pronominal Subjects" of The World Atlas of Language Structures Online, Dryer (2013) distinguishes, from a sample of 711 languages, the following five types.

(3) a. Pronominal subjects are expressed by pronouns in subject position that are normally if not obligatorily present (82 languages).

b. Pronominal subjects are expressed by affixes on verbs (437).

c. Pronominal subjects are expressed by clitics with variable host (32).

d. Pronominal subjects are expressed by subject pronouns that occur in a different syntactic positon from full non phrases (67).

e. Pronominal subjects are expressed only by pronouns in subject position, but these pronouns are often left out (61).

f. More than one of the above types with none dominant (32).

Dryer shows that most languages in which "pronominal subjects are expressed only by pronouns in subject position, but these pronouns are often left out," that is, NSLs with no subject agreement on the verb, are found in East and Southeast Asia or in Australia. On the other hand, languages that have obligatory subjects account for only about $11 \%$ of his sample and are all lumped together in one group, irrespective of having subject agreement on the verb or not. According to Dryer, Northern Europe and West Africa are two areas in which languages with obligatory subjects are particularly common. Moreover, he shows that languages in which "pronominal subjects are expressed by affixes on verbs," which roughly correspond to NSLs with subject agreement on the verb, are much more numerous and geographically widespread than the other types. However, Dryer does not make it clear how rich the agreement in these languages is.

Bisang (2014) calls attention to the fact that East and mainland Southeast Asian languages are NSLs with no subject agreement on the verb, while West African Niger-Congo languages also do not have agreement, but disallow null subjects. According to him, the reason is that the ancestor languages of Niger-Congo had a morphological paradigm expressing the features of person and number on the verb, while the ancestor languages of East and mainland Southeast Asian languages did not. In the Niger-Congo languages, obligatory pronouns took over from the agreement prefixes and kept the frequency of the relevant subject features above the critical percentage for linguistic change of 20-30\% (Bisang 2014:36). However, Bisang's work is restricted to the aforementioned language groups and areas.

As can be seen from the above overview, no large-scale cross-linguistic investigation has yet verified if there is a correlation between agreement richness and occurrence of null subjects, nor has a geographical and genealogical analysis of the existent variation yet been presented.

\section{Methodology}

I have attempted to measure agreement richness in a language by counting the number of person, number and gender (PNG) combinations encoded by subject agreement on the verb. For example, English has two PNG combinations (the third-person singular suffix $-s$ and zero for the other combinations). Such a method is similar to the classification of sound inventories according to the number of vowels and consonants (Maddieson 2013a, 2013b) and the classification of person paradigms according to the number of "roles or combinations of roles in the speech act that each language considers to be of sufficient importance to mark by a separate lexical form" (Ingram 1978:215). This method has some shortcomings, as it does not distinguish, for instance, between 
person and number syncretism, but this approach can nevertheless reveal some meaningful tendencies, as will become clear.

If a language has subject paradigms with different numbers of combinations, I consider the highest number for the purposes of this analysis. For example, Spanish is classified as a language with six combinations, although some paradigms distinguish fewer forms. Nevertheless, subject agreement in the vast majority of languages has the same PNG distinctions, and any differences are generally slight. I also consider sequences of separate agreement markers. For example, if there is an agglutinative language that has three morphological agreement slots on the verb: one for gender (masculine vs feminine), one for number (singular vs plural) and one for person (first, second, and third), this language has in total twelve PNG combinations. Moreover, I will also take into account cases in which PNG is marked by optional morphemes. For example, in Tapiete, a Tupian language spoken in Argentina, the third-person subject is marked by the prefix $o$-, while plurality is marked by the optional suffix -ré (González 2005:143, 190).

I will disregard PNG distinctions that are seen only in the conjugation of a specific verb. For example, English is classified as a language with two PNG distinctions, although the present tense of the verb be distinguishes three forms ( $\mathrm{am}$ in the first-person singular, is in the third-person singular, and are in the remaining combinations). Person portmanteaus (forms that combine the subject and object into one single morpheme) are also disregarded.

This study is based on a sample of 403 languages. The data were extracted mainly from reference grammars. In cases where the information available in grammars was insufficient, I consulted language specialists and academic articles. I attempted to analyze languages from as many families and subfamilies as possible. The number of languages in the sample is more or less proportional to the total number of languages in the respective families. The genealogical classification follows Hammarström et al. (2018). In order to control for geographical bias, the languages are divided into the six areas proposed by Hammarström and Donohue (2014): Africa, Eurasia, Papunesia (all islands between Sumatra and the Americas, excluding Japan and islands to the north of it), Australia, North America (includes Central America and Greenland), and South America. The areal distribution of the languages in the sample is shown in Table 1. As can be seen, all six areas are well represented.

\begin{tabular}{cccccc}
\hline Africa & Eurasia & Papunesia & Australia & North America & South America \\
\hline 75 & 108 & 72 & 37 & 57 & 54 \\
$18 \%$ & $26 \%$ & $17 \%$ & $9 \%$ & $14 \%$ & $13 \%$ \\
\hline \multicolumn{5}{c}{ Table 1. The areal distribution of the languages in the sample $(N=403)$}
\end{tabular}

The analyzed constructions must occur in the main clause of a declarative sentence. Many languages that require overt subjects do not do so in imperative sentences, as English (e.g., Bring me that book). The subject must be thematic, such as I ate almonds. Expletive subjects, such as $I t$ rains, are a separate area of research and are thus disregarded. Coordinate constructions and answers to questions are not considered. Regarding this, Holmberg et al. (2009:66) argue that answers to questions are insensitive to the person of the subject. Finnish, for example, allows firstand second-person null subjects freely, while third-person subjects are obligatory in the main clauses of declarative sentences. However, third-person null subjects are allowed in answer to questions and in subordinate clauses.

The authors of reference grammars generally make clear whether subjects can be omitted. When this is not the case, a language is classified as a non-NSL if all considered constructions 
(including texts) in the source consulted have an overt subject. Otherwise, it is classified as an NSL. Partial NSLs (which allow null subjects only in restricted circumstances, such as Finnish, described above) have only been classified as such if this is clearly stated.

An agreement marker is defined as a dependent form (clitic or affix) that contains the feature of person and marks the single argument of an intransitive verb and/or the agentive argument of a transitive verb. I consider both agreement markers that can co-occur with overt subjects and those that cannot. For example, in Chamorro, an Austronesian language spoken in the Mariana Islands, the subject must be null when there is subject agreement for person on the verb (Chung 2003:552). In this study, only the PNG features are considered. Other features that are not so widespread crosslinguistically, such as politeness and the proximate/obviative distinction, are disregarded. In some cases, I disregarded these less widespread features but retained the rest. For example, the subject clitics of Rukai, an Austronesian language spoken in Taiwan, distinguish between visible/invisible in the third-person singular and plural, as shown in (4). In this case, I disregarded the visible/invisible contrast and considered only the person, number, and clusivity distinctions.

(4) Rukai (Zeitoun 2005:292)

$\begin{array}{ll}\text { 1SG } & -l i \\ \text { 2SG } & -k o \\ \text { 3SG.VIS } & -(n) i \\ \text { 3SG.INVIS } & -d h a \\ \text { 1PL.INCL } & -t a \\ \text { 1PL.EXCL } & -n a i \\ \text { 2PL } & -n o m i \\ \text { 3PL.VIS } & -l-i-n i \\ \text { 3PL.INVIS } & -l-i-d h a\end{array}$

\section{Results}

\subsection{Overall results}

Table 2 shows that NSLs are more frequent than partial and non-NSLs, regardless of the number of PNG combinations. Table 3 shows that, among the NSLs with subject agreement on the verb, NSLs with seven or more combinations are the most frequent in all areas. Table 4 shows that, among the NSLs with subject agreement on the verb, NSLs with seven or more combinations are the most widespread genealogically. Generally, among languages with subject agreement on the verb, the greater the number of PNG combinations, the more geographically and genealogically widespread are the NSLs, as can be seen in Tables 3 and 4. NSLs without subject agreement on the verb are more numerous than NSLs with seven or more combinations only in Eurasia, as can be seen in Table 3. In this area, NSLs without subject agreement on the verb are also more widespread genealogically, as shown in Table 4.

Table 2. Number of NSLs, partial NSLs, and non-NSLs

\begin{tabular}{cccccccc}
\hline & \multicolumn{6}{c}{ Number of PNG combinations } & \\
\cline { 2 - 7 } & No agreement & $2-3$ & 4 & 5 & 6 & 7 or more & Total \\
\hline NSLs & 73 & 5 & 9 & 20 & 84 & 171 & 362
\end{tabular}




\begin{tabular}{lccccccc} 
Partial NSLs & 5 & 2 & 0 & 1 & 2 & 2 & 12 \\
Non-NSLs & 19 & 4 & 2 & 2 & 1 & 1 & 29 \\
Total & 97 & 11 & 11 & 23 & 87 & 174 & 403 \\
\hline
\end{tabular}

Table 3. Number of NSLs, broken up by area

\begin{tabular}{lccccccc}
\hline & \multicolumn{6}{c}{ Number of PNG combinations } & \\
\cline { 2 - 7 } & No agreement & $2-3$ & 4 & 5 & 6 & 7 or more & Total \\
\hline Africa & 3 & 0 & 1 & 3 & 15 & 34 & 56 \\
Eurasia & 34 & 2 & 1 & 5 & 26 & 27 & 95 \\
Papunesia & 17 & 1 & 3 & 3 & 10 & 33 & 67 \\
Australia & 11 & 1 & 1 & 0 & 2 & 22 & 37 \\
North America & 3 & 0 & 1 & 5 & 19 & 28 & 56 \\
South America & 5 & 1 & 2 & 4 & 12 & 27 & 51 \\
Total & 73 & 5 & 9 & 20 & 84 & 171 & 362 \\
\hline
\end{tabular}

Table 4. Number of families with NSLs, broken up by area

\begin{tabular}{lccccccc}
\hline & \multicolumn{5}{c}{ Number of PNG combinations } & \\
\cline { 2 - 6 } & No agreement & $2-3$ & 4 & 5 & 6 & 7 or more & Total \\
\hline Africa & 2 & 0 & 1 & 2 & 9 & 15 & 29 \\
Eurasia & 14 & 2 & 1 & 3 & 12 & 12 & 44 \\
Papunesia & 8 & 1 & 2 & 3 & 5 & 13 & 32 \\
Australia & 2 & 1 & 1 & 0 & 2 & 18 & 24 \\
North America & 3 & 0 & 1 & 5 & 14 & 21 & 44 \\
South America & 5 & 1 & 2 & 4 & 11 & 21 & 44 \\
Total & 34 & 5 & 8 & 17 & 53 & 100 & 217 \\
\hline
\end{tabular}

Creissels (2005:50) warns that the morphemes termed "subject pronouns" in descriptions of African languages are mostly not really separate words and should be reanalyzed as dependent forms. Following this, African non-NSLs without subject agreement on the verb would actually be NSLs with subject agreement on the verb. Nonetheless, languages with seven or more PNG combinations would still remain, among languages with subject agreement on the verb, the most widespread geographically and genealogically. There are 13 African languages among the 19 nonNSLs without subject agreement on the verb. Among these African languages, the "subject pronouns" distinguish seven or more PNG combinations in six languages, six combinations in six languages, and five combinations in one language. In this case, in Africa there would be in total four NSLs with five PNG combinations, 21 NSLs with six combinations, and 40 NSLs with seven or more combinations. Moreover, the number of families would be two for NSLs with five combinations, ten for NSLs with six combinations, and 17 for NSLs with seven or more combinations.

\subsection{Results in detail}

This subsection aims at explaining in more detail the quantitative results in the previous subsection. I will first present the languages without subject agreement on the verb and continue, in increasing order of PNG combinations, to languages that have seven or more combinations.

The majority (13 languages) of the 19 non-NSLs without subject agreement are African 
languages. Among these, the majority (9 languages) are Atlantic-Congo languages. In Eurasia, there are four non-NSLs without subject agreement on the verb: Ingush, a Nakh-Daghestanian language from the Caucasus (Nichols 2011), Swedish, Norwegian, and Danish. In Papunesia, there are two non-NSLs without subject agreement on the verb: Abun, a language isolate of Indonesia (Berry and Berry 1999), and Amis, an Austronesian language spoken in Taiwan (Wu 2006, Chen 2008). Among the five partial NSLs without subject agreement on the verb, there are three African languages of the Atlantic-Congo family: Noon (Soukka 2000), Dii (Bohnhoff 2010), and Yoruba (Timothy Adeyemi Akanbi, personal communication). These three languages allow null subjects only in the third person. The other two partial NSLs without subject agreement on the verb are: Zuni, a language isolate of the USA (Nichols 1997, Newman 1965) that allows null subjects only in the third person, and Yawanawá, a Pano-Tacanan language of Brazil (Paula 2004) that allows only third-person singular null subjects.

The three African NSLs without subject agreement on the verb are Ts'ixa (Fehn 2014) and Khwe (Kilian-Hatz 2008), two Khoe-Kwadi languages of Botsawana, and Xun, a Kxa language spoken in Namibia (Heine and König 2015). Among the 34 Eurasian NSLs without subject agreement on the verb, the majority (26 languages) are spoken in East or Southeast Asia. The other cases are found in the Indian subcontinent (seven languages) and in the Caucasus, where the NakhDaghestanian language Lezgian (Haspelmath 1993) is spoken. Moreover, there is a considerable number (14 languages) of Sino-Tibetan languages among these Eurasian NSLs. Among the 17 NSLs of Papunesia without subject agreement on the verb, the majority (10 languages) are Austronesian languages. The 11 NSLs without subject agreement on the verb of Australia are all Pama-Nyungan languages, except the Tangkic language Kayardild (Evans 1995). The three NSLs without subject agreement on the verb of North America are all spoken in the USA: the YukiWappo language Wappo (Thompson et al. 2006), the Uto-Aztecan language Northern Paiute (Thornes 2003), and the Yokutsan language Yowlumne (Weigel 2005). The NSLs without subject agreement on the verb of South America are Epena Pedee, a Chocoan language of Colombia (Harms 1994), Sanuma, a Yanomamic language of Brazil (Borgman 1990), Iskonawa, a PanoTacanan language of Peru (Zariquiey 2015), Hup, a Nadahup language of Brazil (Epps 2008), and Qawasqar, a Kawesqar language of Chile (Aguilera 2001, Clairis 1985).

The non-NSLs with two to three PNG combinations are Mbodomo, an Atlantic-Congo language spoken in Cameroon, Koiari, a Koiarian language spoken in Papua New Guinea, Dutch, and English. Mbodomo marks, in the simple past and past perfect, first and second person as high tone on the verb, while the third person is marked as low tone on the verb. There is no number distinction (Boyd 1997:95). Koiari marks, in the perfect conjugation, the first- and third-person singular with the suffix $-n u$ and all the remaining person and number combinations with -nua. The imperfect conjugation makes the same paradigmatic distinctions (Dutton 1996:23). Dutch present tense suffixes mark the first-person singular with zero, the second- and third-person singular with - $t$ and the three persons in the plural with -en (De Schutter 1994:455-456).

The partial NSLs with two to three combinations are Trumai, a language isolate spoken in Brazil, and Igbo, an Atlantic-Congo language spoken in Nigeria. Trumai allows only third- person null subjects (Raquel Guirardello, personal communication) and marks the third-person with the enclitics $-n /-e$, while the other person and number combinations are unmarked. Number is expressed by independent words: wan (plural) and $a$ (dual). (Guirardello 1999:55, 95). In Igbo, null subjects are allowed only in the second- and third-person singular (Ogbonna Anyanwu, personal communication). The second-person singular is marked with the clitic $i$ - and the thirdperson singular with the clitic $o-$; the other person and number combinations are unmarked 
(Anyanwu 2012:377).

The NSLs with two to three PNG combinations are the following. Siona, a Tucanoan language spoken in Ecuador, marks the third-person singular feminine of the present tense with the suffix $k o$, third-person singular masculine with - hi, and the other combinations by $-j i \dot{i}$ (Bruil 2014:178). Bunan, a Sino-Tibetan language spoken in India, makes a distinction between first-person and nonfirst person agreement in the past and future tenses. In the past tense, first person singular is marked with $-k i d z a$, first person-plural with $-k i t s^{h} a$, and the other combinations are unmarked (Widmer 2014:562). In the future tense, non-first person singular is marked with -kani:, non-first-person plural by $-k^{h} a k$, and the first-person is unmarked (Widmer 2014:569). Jarawa, a Jarawa-Onge language spoken in the Andaman Islands, distinguishes the three persons, but there is no number distinction. First person is marked with the prefix $m$-, second person with $\eta$-, and third person with $h$ - (Kumar 2012:81). Thao, an Austronesian language spoken in Taiwan, marks the first-person singular actor with the suffix $-k$, the second person-singular with $-n u$, and the other combinations are unmarked. The nominative clitics also have the same PNG distinctions (Wang 2004:189). Ngarla, a Pama-Nyungan language spoken in Australia, marks the third-person dual with -pula, the third-person plural with $-y a$, and the other combinations are unmarked (Westerlund 2015:64).

The non-NSL in the database with four PNG combinations are Anejom, an Austronesian language of Vanuatu, and German. In the nineteenth century, the subject/tense markers of Anejom had a rich agreement system including a dual/trial distinction in the three persons and clusivity. Lynch (2000:92-95) shows that this system is undergoing considerable impoverishment and hypothesizes that the language is developing a four-way paradigm in the aorist: first personsingular is marked with $e k$, second-person singular with $n a$, third-person singular with $e t$, and all persons in the plural by era. As shown by the present tense conjugation of the verb legen 'lay' in (5), German has syncretism between the third-person singular and second-person plural, as well as between the first- and third-person plural. The past suffixes have a slightly different paradigmatic distinction, but the number of PNG combinations is the same. The sample in this study contains no partial NSL with four combinations.

\begin{tabular}{|c|c|c|c|c|c|}
\hline (5) & Germa1 & & (6) & Aghu & an den Heuvel 2016:37) \\
\hline & SG & PL & & $1 \mathrm{SG}$ & dade \\
\hline 1 & lege & legen & & N1SG & $d \bar{a}$ \\
\hline 2 & legest & leget & & 1PL & dadõ̃ \\
\hline 3 & leget & legen & & N1PL & dakenã \\
\hline
\end{tabular}

The NSLs with four combinations are the following. Aghu, a Nuclear Trans New Guinea language spoken in Indonesia, makes a distinction between first person and non-first person, both in the singular and plural, as shown by the conjugation of the verb $d a(k)$ 'hear' in (6). Awa Pit, a Barbacoan language spoken in Colombia (Curnow 1997:181-186, 190), and Wambon (de Vries and de Vries-Wiersma 1992:23) make the same paradigmatic distinctions as Aghu. Nez Perce, a Sahaptian language spoken in the USA, marks the third person with $h i$-, while the first and second person are marked with zero. Singular and plural number are distinguished by suffixes (Rude 1985:33-35). Canela-Krahô, a Nuclear-Macro-Je language spoken in Brazil, marks the first-person exclusive with the prefix $i$-, the first-person inclusive with $\mathrm{pa}^{-}$, the second-person with $a$-, and the third-person with $i h$-. These prefixes are pluralized by the independent form $m e$ (Popjes and Popjes 1986:175). The non-past endings of Darma, a Sino-Tibetan language spoken in India, have syncretism between the second-person singular and first-person plural, and there is no number 
distinction in the third person, as shown in (7). The subject suffixes of Kunuz Nubian, a Nubian language spoken in Sudan, have syncretism between the second- and third-person singular, as well as between the first- and second-person plural, as shown in (8). The subject agreement markers of Kokota, an Austronesian language spoken in the Solomon Islands, mark the first-person exclusive with $a$, the first-person inclusive with $d a$, the second person with $o$, and the third person with $e$. There is no number distinction (Palmer 2009:173). The subject clitics of Nhanda, a Pama-Nyungan language spoken in Australia, distinguish the first-person singular with -wa, the second person singular with -wana, the first-person plural with -nyja, and the other PNG combinations are unmarked (Blevins 2001:84).

\begin{tabular}{lll} 
(7) & \multicolumn{3}{c}{ Darma } & (Willis 2007:353) \\
& SG & PL \\
1 & $-d i$ & $-d \varepsilon n$ \\
2 & $-d \varepsilon n$ & $-d \varepsilon n i$ \\
3 & \multicolumn{2}{c}{$-d a$}
\end{tabular}

$\begin{array}{lll}\text { (8) Kunuz Nubian (Abdel-Hafiz 1988:148) } \\ \text { SG } & \text { PL } \\ 1 & -i & -u \\ 2 & -\varnothing & -u \\ 3 & -\varnothing & -a\end{array}$

The two non-NSLs with five combinations are Icelandic and French. Icelandic is exemplified in (9) by the conjugation of the verb telja 'believe'. In this case, there is syncretism between the second- and third-person singular. The preterite tense of French has the same paradigmatic distinctions (Batchelor and Chebli-Saadi 2011:247). The only partial NSL with five combinations is Irish, which allows null subjects only in non-syncretic verb forms (Mac Congáil 2004:117). The past habitual tense of Irish has syncretism between the third-person singular and second-person plural, as illustrated in (10) by the conjugation of the verb cuir 'put'.

\begin{tabular}{lll} 
(9) & \multicolumn{3}{l}{ Icelandic (Thráinsson 1994:159) } \\
& SG & PL \\
1 & tel & teljum \\
2 & telur & teljið \\
3 & telur & telja
\end{tabular}

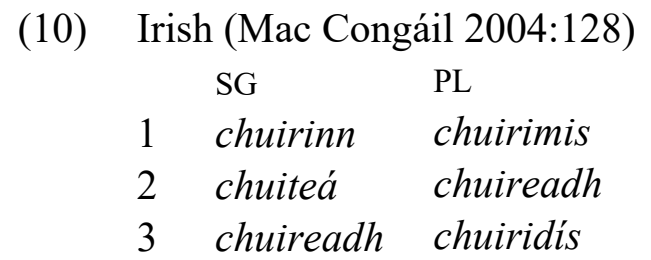

Among the 20 NSLs with five PNG combinations, the most frequent pattern (seen in 11 languages) distinguishes the singular and plural in the first and second person, without number distinction in the third person. This pattern is illustrated in (11) by the subject affixes of Choctaw, a Muskogean language of the USA. The only non-NSL with six combinations is Wutung, a Sko language of Papua New Guinea, which is exemplified in (12) by the conjugation of the verb ha 'go'. There is syncretism between the first-person singular and second-person plural, and no syncretism between the other PNG combinations.

$\begin{array}{ccc} & \text { Choctaw (Broadwell 2006:137) } \\ & \text { SG } & \text { PL } \\ 1 & -l i & \text { il- } \\ 2 & \text { ish- } & \text { hash- } \\ 3 & & \end{array}$

$\begin{array}{ll}\text { (12) } & \text { Wutung (Marmion 2010:300) } \\ \text { 1SG } & \text { ha } \\ \text { 2SG } & \text { hma } \\ \text { 3SG.M } & \text { qa } \\ \text { 3SG.F } & \text { hwang } \\ \text { 1PL } & \text { hna } \\ \text { 2PL } & \text { ha }\end{array}$


3PL hnya

The partial NSLs with six combinations are Kenga, a Central-Sudanic language spoken in Chad, and Finnish. Kenga is exemplified in (13) by the conjugation of the verb àka 'see' in the aorist. This conjugation has no number distinction in the third person, while the other person and number combinations do not display any syncretism. Finnish (Karlsson 1999:61) distinguishes the same PNG combinations as Spanish in (1), that is, the three persons in the singular and plural. Both Kenga (Vandame 1968:35) and Finnish (Karlsson 1999:62) allow null subjects in the first and second, but not in the third person. Among the 84 NSLs in the sample with six PNG combinations, the vast majority (65 languages) have the combinations shown by Spanish in (1).

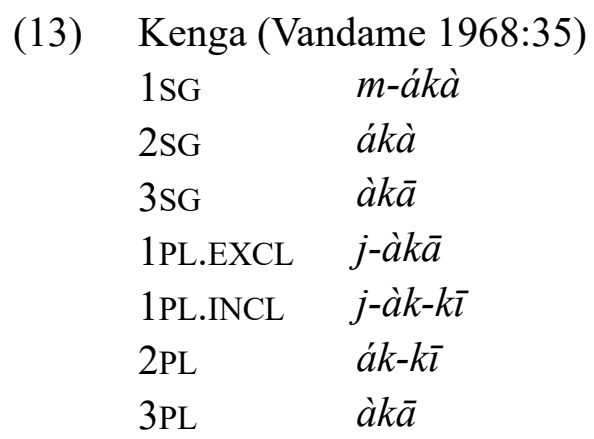

Evenki, a Tungusic language spoken in Russia, is the only non-NSLs in the sample with seven or more PNG combinations. Evenki elaborates the Spanish-type pattern with the addition of an inclusive/exclusive contrast, as seen in (14) by the present conjugation of the verb baka- 'find'. The partial NSLs with seven or more combinations are Mekens, a Tupian language spoken in Brazil, and Modern Hebrew. In Mekens, intransitive subjects can be omitted, while transitive subjects can be omitted only in the third-person singular (Galucio 2001:78, 80). Mekens makes the same person and number distinctions as Evenki in example (14). According to Glinert (1989:53), Modern Hebrew allows null subjects in the past and future tenses, but in the present tense null subjects are allowed only in the third person. The past tense conjugation of the verb saper 'tell' in (15) elaborates the Spanish-type pattern with the addition of masculine/feminine gender in the second- and third-person singular and in the second-person plural.

$\begin{array}{ll}\text { Evenki (Nedjalkov 1997:259) } \\ \text { 1SG } & \text { bakad'am } \\ \text { 2SG } & \text { bakad'anni } \\ \text { 3SG } & \text { bakad'aran } \\ \text { 1PL.EXCL } & \text { bakad'arav } \\ \text { 1PL.INCL } & \text { bakad'arap } \\ \text { 2PL } & \text { bakad'aras } \\ \text { 3PL } & \text { bakad'ara }\end{array}$

$\begin{array}{ll}\text { Modern } & \text { Hebrew (Berman 1997:318) } \\ \text { 1SG } & \text { sipárti } \\ \text { 2SG.M } & \text { sipárta } \\ \text { 2SG.F } & \text { sipárt } \\ \text { 3 SG.M } & \text { siper } \\ 3 \text { SG.F } & \text { sipra } \\ 1 \text { PL } & \text { sipárnu } \\ 2 \text { PL.M } & \text { sipartem } \\ 2 \text { PL.F } & \text { siparten } \\ 3 \text { PL } & \text { sipru }\end{array}$

Unlike among the NSLs with five and six PNG combinations, there is no specific pattern that is 
considerably frequent among the 171 NSLs with seven or more combinations. The most frequent pattern (seen in 25 languages) has the same seven distinctions as the Evenki example in (14).

\section{Conclusion}

In this paper, I examined the correlation between agreement richness and the occurrence of null subjects based on a sample of 403 languages. Agreement richness was measured according to the number of PNG combinations encoded by subject agreement on the verb. It was found that, among languages with subject agreement on the verb, NSLs with seven or more combinations are the most widespread geographically and genealogically. NSLs without subject agreement on the verb are more widespread than NSLs with seven or more combinations only in Eurasia. The findings confirm the generally assumed view that languages with rich subject agreement on the verb tend to allow null subjects, since such languages are well spread geographically and genealogically.

A possible explanation for this tendency is economy, which is a propensity to economize time and effort in the expression and interpretation of constructions. The relationship between null subjects and agreement richness investigated here is an example of the principle of economy working on language: in order to prevent the use of an overt subject or the reliance on contextual information, languages tend to encode clear information on the PNG of the subject through subject agreement on the verb.

However, languages are not always economical. As seen previously, Evenki has unambiguous information on the person and number of the subject and nevertheless requires overt subjects. Moreover, rich agreement systems might become poorer sometimes (Siewierska 2004:277-281). In fact, when languages without subject agreement on the verb are considered, NSLs with seven or more combinations are not the most geographically and genealogically widespread, as the results showed. Therefore, another explanation that must be taken into account is the specific histories of each family.

Since this is a large-scale cross-linguistic study, some distinctions could not be easily made. For example, there might be more partial NSLs than it were found, as the authors of reference grammars sometimes do not pay due attention to null subject phenomena. Another distinction that could not be addressed here is that some NSLs are more likely to omit the subject than others (Cole 2010, Posio 2012). Future research might deal with these distinctions among genealogically and areally diverse languages.

\section{Appendix}

The following is a list of the 403 languages in the sample. The languages are divided into the six areas proposed by Hammarström and Donohue (2014) and the families according to Hammarström et al. (2018) are given in parentheses.

AFRICA: Amharic, Egyptian Arabic, Tamazight, Tamashek, Hausa, Somali, Oromo, Lele, Iraqw, Coptic (Afro-Asiatic); Godié, Kisi, Wolof, Dii, Yoruba, Eleme, Oko, Kar, Fyem, Zulu, Cicipu, Igbo, Kujireray, Temne, Degema, Oshindonga, Mbodomo, Mbalanhu, Koromfe, Chichewa, Babungo, Balanta, Gbaya, Ewe, Dagaare, Noon, Northern Sotho, Shona, Sango, Lucazi, Eton, Swahili, Nzadi, Gola (Atlantic-Congo); Dholuo, Lango, Turkana, Anywa (Nilotic); Chabu, Kunama, Laal, Sandawe, Siamou (Isolates); Lumun (Narrow Talodi); Deiga (KadugliKrongo); Fur (Furan); Haro (Ta-Ne-Omotic); Hoa, Xun (Kxa); Ik (Kuliak); Jamsay (Dogon); 
Kabba, Kenga, Mbay (Central Sudanic); Kanuri (Saharan); Koyra Chiini, Tadaksahak (Songhay); Maba (Maban); Mano, Zialo (Mande); Murle (Surmic); Ts'ixa, Khwe (KhoeKwadi); Kunuz Nubian (Nubian); Tira (Heibanic).

EURASIA: Abkhaz, Kabardian (Abkhaz-Adyge); Kham, Sunwar, Bunan, Ersu, Mishmi, Burmese, Hkongso, Dhimal, Darma, Tangam, Mandarin, Meithei, Dzongkha, Lepcha, Tujia, Eastern Kayah Li, Rabha, Tibetan, Bai (Sino-Tibetan); Ainu (Ainu); Albanian, German, Bulgarian, Pashto, Spanish, Icelandic, French, Persian, Latin, Punjabi, Czech, Russian, Polish, Lithuanian, Irish, Sinhala, Latvian, Urdu, Hindi, Armenian, Marathi, Dutch, Romanian, Sanskrit, Kashmiri, Italian, Portuguese, Modern Greek, Danish, Norwegian, Swedish, English (Indo-European); Modern Hebrew, Gulf Arabic (Afro-Asiatic); Basque, Burushaski, Kusunda, Nihali, Nivkh (Isolates); Gadaba, Malayalam, Brahui, Tamil, Telugu, Kannada (Dravidian); Buriat, Mangghuer, Mongolian (Mongolic); Chukchi, Itelmen (Chukotko-Kamchatkan); Hungarian, Estonian, Tundra Nenets, Finnish, Pite Saami (Uralic); Manchu, Evenki, Udihe (Tungusic); Georgian, Svan (Kartvelian); Great Andamanese (Great Andamanese); Ingush, Lezgian (Nakh-Daghestanian); Jarawa (Jarawa-Onge); Western Yugur, Turkmen, Uzbek, Kirghiz, Kazakh, Turkish, Turfan Uyghur (Turkic); Ket (Yeniseian); Mundari, Pnar, Semelai, Vietnamese, Chrau, Korku, Khmer (Austroasiatic); Japanese (Japonic); Korean (Koreanic); Zoulei, Lao, Thai (Tai-Kadai); Xong (Hmong-Mien); Kolyma Yukaghir (Yukaghir).

AUSTRALIA: Duunidjawu, Nhanda, Ngarla, Kalkatungu, Yanyuwa, Dyirbal, Kuuk Thaayorre, Diyari, Kuku Yalanji, Yidin, Bāgandji, Wargamay, Wangurri, Warrongo, Wangkajunga, Martuthunira, Wirangu (Pama-Nyungan); Bininj Gun-Wok, Enindhilyakwa (Gunwinyguan); Bunuba (Bunaban); Emmi (Western Daly); Gaagudju, Tiwi, Wagiman (Isolates); Kayardild, Yukulta (Tangkic); Limilngan (Limilngan-Wulna); MalakMalak (Northern Daly); Mangarayi (Mangarrayi-Maran); Mawng (Iwaidjan Proper); Nakkara (Maningrida); Ngan'gityemerri (Southern Daly); Nyulnyul, Yawuru (Nyulnyulan); Wambaya (Mirndi); Wardaman (Yangmanic); Worrorra (Worrorran).

PAPUNESIA: Abau, Mehek (Sepik); Abun, Bilua, Duna, Lavukaleve, Maybrat (Isolates); Dom, Tauya, Yagaria, Aghu, Korafe, Usan, Ma Manda, Kewapi, Fore, Lower Grand Valley Dani, Una, Mauwake, Wambon (Nuclear Trans New Guinea); Amanab, Imonda (Border); Amis, Fehan Tetun, Indonesian, Maori, Kokota, Lha'alua, Anejom, Gayo, Cebuano, Yapese, Rukai, Puyuma, Paiwan, Buru, Tondano, Rapanui, Kwamera, Tukang Besi, Tinrin, Thao, Woleaian, Chamorro, Big Nambas, Madurese, Ida'an, Atayal, Amis, Javanese, Samoan, Hawaiian, Niuean, Mualang, Ilocano (Austronesian); Olo, Au, Yeri (Nuclear Torricelli); Barupu, Wutung (Sko); Bauzi (Geelvink Bay); Daga (Dagan); Iatmul, Manambu (Ndu); Kapau (Angan); Koiari (Koiarian); Komnzo (Morehead-Wasur); Kunimaipa (Goilalan); Teiwa, Makalero (TimorAlor-Pantar); Motuna (South Bougainville); Ternate (North Halmahera); Yimas (Lower Sepik-Ramu).

NORTH AMERICA: Laguna Keres (Keresan); Slave, Navaho, San Carlos Apache, Tlingit (Athabaskan-Eyak-Tlingit); Arapaho, Plains Cree, Nishnaabemwin, Yurok (Algic); Assiniboine, Lakhota, Biloxi, Tutelo (Siouan); Cherokee, Seneca, Oneida (Iroquoian); Chimariko, Euchee, Kutenai, Molalla, Seri, Washo, Zuni (Isolates); Choctaw (Muskogean); Chol, Huastec, Itzaj Maya (Mayan); Lowland Chontal (Tequistlatecan); Ineseño Chumash (Chumashan); Cupeño, Warihio, Northern Paiute, Classical Nahuatl, Southeastern Tepehuan, Pipil (Uto-Aztecan); West Greenlandic, Central Alaskan Yupik (Eskimo-Aleut); Guazacapán (Xincan); Hualapai, Maricopa (Cochimi-Yuman); San Francisco del Mar Huave (Huavean); Huehuetla Tepehua (Totonacan); Kiowa (Kiowa-Tanoan); Maidu (Maiduan); Chalcatongo 
Mixtec, Otomí (Otomanguean); Yakima, Nez Perce (Sahaptian); Nuuchahnulth (Wakashan); Nxa'amxcin (Salishan); Teribe, Pech (Chibchan); Southern Pomo (Pomoan); Sierra Popoluca (Mixe-Zoque); Wappo (Yuki-Wappo); Wichita (Caddoan); Yowlumne (Yokutsan).

SOUTH AMERICA: Apalai, Wai Wai, Kuikuro, Tiriyó (Cariban); Ashéninka Perené, Paresi-Haliti, Warekena, Tariana (Arawakan); Awa Pit (Barbacoan); Muylaq' Aymara (Aymaran); Betoi, Guató, Iatê, Kanoê, Kwaza, Movima, Muniche, Mỹky, Páez, Trumai, Puinave, Yurakaré, Urarina (Isolates); Karajá, Canela-Krahô, Maxakalí (Nuclear-Macro-Je); Iskonawa, Yawanawá, Cavineña (Pano-Tacanan); Cubeo, Ecuadorian Siona (Tucanoan); Epena Pedee (Chocoan); Hup (Nadahup); Ika (Chibchan); Kamaiurá, Mundurukú, Tapiete, Mekens, UrubuKapoor (Tupian); Kulina (Arawan); Mako (Jodi-Saliban); Mamaindê (Nambiquaran); Mapuche (Araucanian); Ocaina (Huitotoan); Pilagá (Guaicuruan); Qawasqar (Kawesqar); Huallaga Quechua, Imbabura Quechua (Quechuan); Sanapaná (Lengua-Mascoy); Sanuma (Yanomamic); Tehuelche (Chonan); Wampis (Chicham); Wari (Chapacuran); Wichí (Matacoan).

\section{References}

Abdel-Hafiz, Ahmed S. 1988. A reference grammar of Kunuz Nubian. Ph.D. Dissertation, State University of New York at Buffalo.

Aguilera, Oscar. 2001. Gramática de la lengua Kawésqar. Temuco: Corporación de Desarrollo Indígena.

Anyanwu, Ogbonna. 2012. Pronominal Subject Clitics in Igbo. Theory and Practice in Language Studies, Vol. 2, No. 2, pp. 377-388.

Batchelor, R.E. and Chebli-Saadi, M. 2011. A Reference Grammar of French. Cambridge: Cambridge University Press.

Berman, Ruth A. 1997. Modern Hebrew. In Robert Hetzron (ed.) The Semitic Languages. London: Routledge.

Berry, Keith and Berry, Christine. 1999. A Description of Abun: A West Papuan Language of Irian Jaya (Pacific Linguistics, Series B, 115.) Canberra: Australian National University.

Bisang, Walter. 2014. On the strength of morphological paradigms: a historical account of radical pro-drop. In Martine Robbeets and Walter Bisang (eds.). Paradigm change: In the Transeurasian languages and beyond. Amsterdam: John Benjamins, 23-60.

Blevins, Juliette. 2001. Nhanda: an Aboriginal Language of Western Australia. University of Hawaii Press.

Bohnhoff, Lee Edward. 2010. A description of Dii: Phonology, grammar, and discourse. Ngaoundéré, Cameroun: Dii Literature Team.

Borgman, Donald M. 1990. Sanuma. In Desmond C. Derbyshire and Geoffrey K. Pullum (eds.), Handbook of Amazonian Languages, 15-248. Berlin: Mouton de Gruyter.

Boyd, Virginia L. 1997. A Phonology and Grammar of Mbódómó. MA thesis, University of Texas at Arlington.

Broadwell, George Aaron. 2006. A Choctaw Reference Grammar. Lincoln: University of Nebraska Press.

Bruil, Martine. 2014. Clause-typing and evidentiality in Ecuadorian Siona. Ph.D. dissertation, Rijksuniversiteit te Leiden.

Camacho, José. 2013. Null Subjects. Cambridge: Cambridge University Press.

Chen, Yi-Ting. 2008. A minimalist approach to Amis structure and complementation. Ph.D. 
dissertation, Arizona State University.

Chung, Sandra. 2003. The syntax and prosody of weak pronouns in Chamorro. Linguistic Inquiry 3, pp. 547-599.

Clairis, Christos. 1985. El Qawasqar: Lingüística Fueguina, Teoría y Descripción. (Estudios Filológicos: Anejo, 12.) Valdivia: Universidad Austral de Chile.

Cole, Melvyn. 2010. Thematic null subjects and accessibility. Studia Linguistica 63(3), pp. 271320.

Creissels, Dennis. 2005. A typology of subject and object markers in African languages. In Erhard Voeltz (ed.) Studies in African linguistic typology. Amsterdam: John Benjamins.

Curnow, Timothy. 1997. A grammar of Awa Pit (Cuaiquier): An indigenous language of southwestern Colombia. Ph.D. dissertation, Australian National University.

Cysouw, Michael. 2003. The paradigmatic structure of person marking. Oxford: Oxford University Press.

D’Alessandro, Roberta. 2015. Null subjects. In: Antonio Fábregas, Jaume Mateu and Michael Putnam (eds), Contemporary Linguistic Parameters. London: Bloomsbury Press, pp. 201-226.

De Schutter, Georges. 1994. Dutch. In Ekkehard König and Johan van der Auwera (eds.), 439-77.

Dryer, Matthew S. 2013. Expression of Pronominal Subjects. In: Matthew S. Dryer and Martin Haspelmath (eds.).

Dryer, Matthew S. and Haspelmath, Martin (eds.). 2013. The World Atlas of Language Structures Online. Leipzig: Max Planck Institute for Evolutionary Anthropology. (Available online at http://wals.info, Accessed on 2019-01-19.).

Dutton, Tom E. 1996. Koiari. (Languages of the World/Materials, 10.) München: Lincom.

Evans, Nicholas D. 1995. A Grammar of Kayardild: With Historical-Comparative Notes on Tangkic. (Mouton Grammar Library, 15.) Berlin, New York: Mouton de Gruyter.

Epps, Patience. 2008. A Grammar of Hup. (Mouton Grammar Library, 43.) Berlin, New York: Berlin: Mouton de Gruyter.

Fehn, Anne-Maria. 2014. A Grammar of Ts'ixa (Kalahari Khoe). Ph.D. dissertation, Universität zu Köln.

Gilligan, Gary Martin. 1987. A cross-linguistic approach to the pro-drop parameter. Ph.D. dissertation, University of Southern California.

Galucio, Ana Vilacy. 2001. The morphosyntax of Mekens (Tupi). Ph.D. dissertation, University of Chicago.

Glinert, Lewis. 1989. The grammar of Modern Hebrew. Cambridge: Cambridge University Press. González, Hebe Alicia. 2005. A grammar of Tapiete (Tupi-Guarani). Ph.D. dissertation, University of Pittsburgh.

Guirardello, Raquel . 1999. A reference grammar of Trumai. Ph.D. dissertation, Houston: Rice University.

Hammarström, Harald and Forkel, Robert and Haspelmath, Martin. 2018. Glottolog 3.3. Jena: Max Planck Institute for the Science of Human History. (Available online at http://glottolog.org, Accessed on 2019-01-19.)

Hammarström, Harald and Donohue, Mark. 2014. Some principles on the use of macro-areas in typological comparison. Language Dynamics and Change 4.1: 167-187.

Harms, Philip L. 1994. Epena Pedee Syntax. (Summer Institute of Linguistics: Publications in Linguistics, 118.) Dallas: The Summer Institute of Linguistics and the University of Texas at Arlington.

Haspelmath, Martin. 1993. A Grammar of Lezgian. Berlin: Mouton de Gruyter. 
Heine, Bernd and König, Christa. 2015. The !Xun Language: A Dialect Grammar of Northern Khoisan. Cologne: Köppe.

van den Heuvel, Wilco. 2016. Aghu: Annotated Texts with Grammatical Introduction and Vocabulary Lists. (Asia-Pacific Linguistics, 33.) Canberra: Australian National University.

Holmberg, Anders and Nayudu, Aarti and Sheehan, Michelle. 2009. Three partial null-subject languages: a comparison of Brazilian Portuguese, Finnish and Marathi. Studia Linguistica 63.1: 59-97.

Ingram, David. 1978. Typology and universals of personal pronouns. In Joseph H. Greenberg (ed.), Universals of human language, vol. iii: Word Structure: 213-248. Stanford: Stanford University Press.

Jaeggli, Osvaldo, and Kenneth J. Safir. 1989. The null subject parameter and parametric theory. In Osvaldo Jaeggli and Kenneth J. Safir (eds.), The null subject parameter. Springer, Dordrecht. $1-44$.

Karlsson, Fred. 1999. Finnish: An Essential Grammar. London: Routledge.

Kilian-Hatz, Christa. 2008. A Grammar of Modern Khwe (Central Khoisan). Köln: Köppe.

König, Ekkehard and Johan van der Auwera (eds.). 1994. The Germanic Languages. London: Routledge.

Kumar, Pramod. 2012. Descriptive and typological study of Jarawa. Ph.D. dissertation, New Delhi: Jawaharlal Nehru University.

Lynch, John. 2000. A Grammar of Anejom. (Pacific Linguistics, 507.) Pacific Linguistics. Canberra: Canberra: Research School of Pacific and Asian Studies, Australian National University.

Mac Congáil, Nollaig. 2004. Irish grammar book. Indreabhán: Cló Iar-Chonnachta.

Maddieson, Ian. 2013a. "Consonant Inventories". In Matthew S. Dryer and Martin Haspelmath, (eds.).

Maddieson, Ian. 2013b. "Vowel Quality Inventories". In Matthew S. Dryer and Martin Haspelmath, (eds.).

Marmion, Douglas E. 2010. Topics in the phonology and morphology of Wutung. Ph.D. dissertation, Australian National University.

Modesto, Marcello. Topic prominence and null subjects. 2008. In Theresa Biberauer (ed.). The Limits of Syntactic Variation. Amsterdam: John Benjamins.

Müller, Gereon. 2006. Pro-drop and impoverishment. In: Form, structure, and grammar. A festschrift presented to Günther Grewendorf on occasion of his 60th birthday, 93-115.

Nedjalkov, Igor. 1997. Evenki. London: Routledge.

Neeleman, Ad and Szendröi, Kriszta. 2007. Radical pro drop and the morphology of pronouns. Linguistic Inquiry 38.4:671-714.

Newman, Stanley. 1965. Zuni Grammar. (University of New Mexico Publications in Anthropology, 14.) Albuquerque: The University of New Mexico Press.

Nichols, Lynn. 1997. Topics in Zuni Syntax. Ph.D. dissertation, Harvard University.

Nichols, Johanna. 2011. Ingush Grammar. University of California Press.

Olsen, Neil H. 2014. A descriptive grammar of Koho-Sre: A Mon-Khmer Language. Ph.D. dissertation, University of Utah.

Palmer, Bill. 2009. Kokota Grammar. (Oceanic Linguistics Special Publication, 35.) Honolulu: University of Hawaii Press.

Paula, Aldir Santos de. 2004. A língua dos índios Yawanawá do Acre. Ph.D. dissertation, Universidade Estadual de Campinas. 
Popjes, Jack and Popjes, Jo. 1986. Canela-Krahô. In Desmond C. Derbyshire and Geoffrey K. Pullum. Handbook of Amazonian Languages, vol. I. Berlin: Mouton de Gruyter.

Posio, Pekka. 2012. Pronominal subjects in European Portuguese and Peninsular Spanish. Ph.D. dissertation, University of Helsinki.

Roberts, Ian and and Holmberg, Anders. 2010. Introduction: parameters in minimalist theory. In: Biberauer, Theresa, Holmberg, Anders, Roberts, Ian, and Sheehan, Michelle. Parametric Variation: Null Subjects in Minimalist Theory. Cambridge: Cambridge University Press, pp. $1-57$.

Rude, Noel E. 1985. Studies in Nez Perce grammar and discourse. Ph.D. dissertation, University of Oregon.

Siewierska, Anna. 2004. Person. Cambridge: Cambridge University Press.

Soukka, Maria. 2000. A Descriptive Grammar of Noon: A Cangin Language of Senegal. München: Lincom.

Speas, Margaret. Economy, agreement, and the representation of null arguments. 2006. In Peter Ackema and Patrick Brandt and Maaike Schoorlemmer and Fred Weerman (eds.). Arguments and agreement. Oxford: Oxford University Press.

Thompson, Sandra A. and Park, Joseph Sung-Yul and Li, Charles N. 2006. A Reference Grammar of Wappo. Berkeley and Los Angeles: University of California Press.

Thornes, Timothy Jon. 2003. A Northern Paiute Grammar and Texts. Ph.D. dissertation, University of Oregon.

Thráinsson, Höskuldur. 1994. Icelandic. In Ekkehard König and Johan van der Auwera (eds.), 142189.

Vandame, Charles. 1968. Grammaire Kenga. (Études Linguistiques, 2.) Paris: Afrique et Language. de Vries, Lourens and de Vries-Wiersma, Robinia. 1992. The Morphology of Wambon of the Irian Jaya Upper-Digul Area. Leiden: The KITLV Press.

Wang, Shan-Shan. 2004. An ergative view of Thao syntax. Ph.D. dissertation, University of Hawaii at Manoa.

Weigel, William Frederick. 2005. Yowlumne in the twentieth century. Ph.D. dissertation, University of California at Berkeley.

Westerlund, Torbjörn. 2015. A Grammatical Sketch of Ngarla (Ngayarta, Pama-Nyungan). Canberra: Asia-Pacific Linguistics.

Widmer, Manuel. 2014. A descriptive grammar of Bunan. Ph.D. dissertation, Universität Bern.

Willis, Christina M. 2007. A descriptive grammar of Darma: an endangered Tibeto-Burman language. Ph.D. dissertation, University of Texas at Austin.

Wu, Jing-lan Joy. 2006. Verb classification, case marking, and grammatical relations in Amis. Ph.D. dissertation, State University of New York at Buffalo.

Zariquiey, Roberto. 2015. Bosquejo gramatical de la lengua iskonawa. Lima / Boston: Latinoamericana Editores / CELACP / Revista de Crítica Literaria Latinoa.

Zeitoun, Elizabeth. 2005. A Grammar of Mantauran (Rukai). Taipei: Academica Sinica. 